UDK 37.018.26

Originalni naučni rad

Primljeno: 30.9.2017.

Odobreno za štampu: 1.12.2017.

DOI: https://doi.org/10.46630/gped.1.2017.01

\title{
UKLJUČENOST RODITELJA U ŠKOLSKE AKTIVNOSTI ${ }^{1}$
}

\author{
Marina Matejevićé, Marija Jovanović \\ Univerzitet u Nišu, Filozofski fakultet u Nišu, Departman za pedagogiju
}

\begin{abstract}
Apstrakt: U radu se razmatra problem uključenosti roditelja u školske aktivnosti. Kao teorijsko polazište navodi se model Epsteinove (Epstein, 2016), i ukazuje na probleme ostvarivanja partnerstva porodice i škole, u kontekstu uključivanja roditelja u školske aktivnosti. Istraživanje je organizovano sa ciljem da se utvrde oblici uključenosti roditelja u školske aktivnosti, i razlike u odnosu na pol i nivo obrazovanja roditelja, i uspeh i uzrast učenika. Rezultati istraživanja su pokazali da se uključenost roditelja u aktivnosti škole prema tipologiji Epsteinove nalazi na nivou komunikacije, pomoći u učenju kod kuće i volotiranja, pri čemu je škola otvorena za saradnju, ukoliko sami roditelji pokažu inicijativu za uključivanje u školske aktivnosti. Rezultati istraživanja su pokazali da su majke više uključene u školske aktivnosti, da imaju inicijativu za uspostavljanje partnerstva sa školom, dok očevi očekuju inicijativu škole. U odnosu na nivo obrazovanja roditelja, utvrđeno je da postoji statistički značajna razlika između uključenosti očeva i nivoa obrazovanja, kod majki ove razlike nisu utvrđene. Kod mlađih učenika je uključenost roditelja u školske aktivnosti veća, što je u saglasnosti i sa nekim ranijim istraživanjima. Takođe je utvrđena povezanost uključenosti roditelja u školske aktivnosti sa uspehom učenika, roditelji koji su pokazali veći stepen uključenosti, imaju decu sa boljim školskim postignućima. Implikacije dobijenih nalaza ukazuju da je potrebno da škola preuzme inicijativu za organizovanje partnerstva sa porodicom, u kontekstu korišćenja različitih mogućnosti uključivanja roditelja i negovanja partnerstva, s obzirom da porodica i škola, imaju zajedničke interese i odgovornosti prema deci u stvaranju boljih programa i prilika za razvoj i postignuća učenika.
\end{abstract}

Ključne reči: uključenost roditelja, školske aktivnosti, partnerstvo porodice $i$ škole.

\section{Problemi partnerstva porodice i škole}

Proučavanje uključenosti roditelja u školske aktivnosti, iz istorijske perspektive, pokazuje da je odnos između roditelja i škole uglavnom bio problematičan na različite

\footnotetext{
${ }^{1}$ Napomena: Rad je deo makroprojekta 179074 koji je finansiran od strane Ministarstva za nauku i tehnološki razvoj.

${ }^{2}$ marina.matejevic@filozofski.rs
} 
načine. Roditelji su najpre bili isključivani kao neadekvatni, kako je nekada konstatovao Pestaloci, decu je najpre trebalo izdvojiti iz zaostale porodične sredine, da bi tokom vekova sistematsko i blagotvorno dejstvo škole dovelo početkom XX veka do stvaranja populacije školovanih roditelja koji su mogli da razumeju ciljve obrazovanja i da se uključe u saradnju sa školom. Roditelji su bili potrebni školi kao „produžena ruka" školskog sistema, i tako je utemeljen jedan diskurs saradnje porodice i škole koji je predstavljao istorijski zaokret u odnosu na Pestalocijevo vreme (Džinović i dr., 2007).

Veće pridavanje značaja ulozi roditelja i njihovom aktivnijem uključivanju u rad škole možemo posmatrati kao deo širih procesa decentralizacije i demokratizacije obrazovanja. U suštini, porodica i škola su dva najznačajnija sistema kojima dete pripada, prirodno i razumljivo bi bilo da postoji partnerstvo između porodice i škole. Međutim, iako se promoviše ideja o partnerstvu porodice i škole, izgleda da postoje problemi u negovanju partnerstva. Način na koji se škole brinu o deci reflektuje se na način kako se odnose prema njihovim porodicama. Ako nastavnici posmatraju decu jednostavno samo kao učenike, verovatno će i njihov odnos prema porodici biti specifičan u kontekstu očekivanja koja imaju od porodice. To bi značilo da se od porodice očekuje da obavlja svoju vaspitnu funkciju i da ostavi školi da se stara o obrazovanju učenika. Ako nastvanici posmatraju učenike kao decu, verovatno će sagledati i porodicu kao partnera koji zajedno sa školom učestvuje u dečijem razvoju i obrazovanju. U takvom partnerstvu porodica i škola, prepoznaju zajedničke interese i odgovornosti prema deci, i zajedno rade kako bi stvorili bolje programe i prilike za razvoj i postignuća učenika.

Ipak, iako su ustanovljeni različiti oblici saradnje porodice i škole, problem uključenosti roditelja u školske aktivnosti je i dalje prisutan, između ostalog, i usled različitih domena funkcionisanja porodice i škole. Škola funkcioniše na opštijem institucionalnom nivou, njen nastanak, položaj, obeležja i pravila funkcionisanja su određeni društvenom strategijom, dolaze „odozgo i spolja”, u okviru javnog funkcionisanja. Porodica predstavlja bazičniji sistem po prirodi i brojnosti potreba koje se kroz nju zadovoljavaju, po prirodi i dužini trajanja uspostavljenih veza, po značaju ukupnih, a pre svega emocionalnih investicija u dete. Nastanak, obeležja i pravila funkcionisanja porodice određeni su, u najvećoj meri, subjektivitetom njenih članova, neposredno dolaze „odozdo i iznutra”, iz domena privatnog funkcionisanja. Iz ove početne sistemske neravnoteže stvaraju se pretpostavke za druge vrste neravnoteža (Polovina, 2007), koje ugrožavaju uspostavljanje partnerstva porodice i škole.

Postoji mnogo razloga zbog kojih je potrebno da se razvija partnerstvo porodice i škole, ono može obezbediti podršku porodicama u vaspitanju dece, može unaprediti njihove veštine roditeljstva, povezati porodice u okviru škole i zajednice, takođe može pružiti podršku nastavnicima u radu. Međutim, glavni razlozi za negovanje partnerstva su pomoć i podrška učenicima u ostvarivanju uspeha u školi kao i u kasnijem životu. Kada roditelji, nastavnici i učenici počnu da posmatraju jedni druge kao partnere u procesu vaspitanja i obrazovanja, stvoriće se uslovi da škola funkcioniše kao brižna društvena zajednica. 


\section{Oblici uključivanja roditelja u školske aktivnosti}

U literaturi se navode različiti oblici uključivanja roditelja u rad škole, a samim tim i u školske aktivnosti dece. Na osnovu stepena uključenosti roditelja u školske aktivnosti, neki autori razlikuju četiri tipa roditelja: partnere, učesnike, delegate i nevidljive roditelje (Driessen, et al., 2005). Roditelji partneri i roditelji učesnici veoma su zainteresovani za saradnju sa školom koju dete pohađa. Roditelji partneri aktivni su i na polju formalne participacije, dok nevidljivi roditelji u najmanjem stepenu učestvuju u različitim školskim aktivnostima.

Svap (Swap, 1993) navodi četiri različita praktična modela uključivanja roditelja u školske aktivnosti: zaštitni model, model „od škole do kuće“, model obogaćivanja nastavnog plana i programa i partnerski model.

Prema „zaštitnom modelu“ roditelji delegiraju odgovornosti za obrazovanje dece na školu i proglašavaju školu odgovornom za postignute rezultate. Ovaj model predstavlja teoriju da kuća i škola imaju jedinstvene misije i ciljeve, ali da roditelji i nastavnici imaju posebne uloge i uticaje u razvoju dece. Kada se ovaj model primeni u školama, roditelji mogu biti retko uključeni ili uključeni sa ograničenjima, npr. doniraju sredstva, prate decu na putovanjima, ili pružaju neke druge usluge. Škole koje praktikuju ovaj model verovatno neće primeniti niti podržati komunikaciju roditelja i nastavnika, niti sprovoditi aktivnosti u kojima se roditelji posmatraju kao jednako odgovorni za obrazovanje deteta ili dovoditi u vezu sa donošenjem školskih odluka.

Model „od škole do kuće“ prepoznaje vrednost i snagu uticaja porodice na obrazovanje deteta, ali ističe samo jednosmernu komunikaciju „od škole do kuće“. Ovaj model pretpostavlja da roditelji treba da se slože sa programom i ciljevima škole. Nastavnici mogu davati informacije o školskim aktivnostima, slabostima i prednostima učenika, školskoj politici, nastavnom planu i programu i drugo. Međutim, škola ne pruža mogućnost roditeljima ili drugim članovima zajednice da daju svoje ideje, mišljenja, da utiču na politiku škole, kao ni školske odluke ili da na bilo koji način utiču na školski program, nastavnu praksu i obrazovanje učenika.

Ova dva modela ograničavaju uključenost roditelja i njihovu ulogu u školi i obrazovanju deteta. Oni ne integrišu porodicu, znanja, vrednosti, talenate, tradiciju, kulturu, potencijale roditelja, sa planom i programom škole i školskim životom. Umesto toga oni štite nastavnike, gradeći oko škole figurativne zidove, pretpostavljajući da su nastavnici i škola zaduženi za formalno obrazovanje dece.

Prema modelu obogaćivanja nastavnog plana i programa, moguće je da roditelji, nastavnici i deca uče jedni od drugih. Ovaj model integriše mogućnosti i kapacitete porodice i znanja i tradiciju zajednice u školski program. Međutim, sam model obogaćivanja nastavnog plana i programa nije sveobuhvatni program škole, porodice i učenika, te je potrebno uzeti u obzir i druge oblike angažovanja u školi, koji mogu da poboljšaju proces učenja učenika kroz različite oblike uključivanja roditelja.

Model partnerstva je teorijski koncept prema kome se preklapaju uticaji porodice i škole (Epstein, 2016). Partnerski model je koncipiran na međusobnom 
poštovanju, zajedničkom učešću porodice i nastavnika na mnogim nivoima aktivnosti, i deljenju odgovornosti za planiranje i donošenje odluka. U partnerskom modelu roditelji i nastavnici, zajedno planiraju, implementiraju i ocenjuju aktivnosti, koje pomažu učenicima da ostvare ciljeve učenja i ponašanja. Ovakav program obuhvata roditeljsku uključenost u razvoj dece i adolescenata, dvosmernu komunikaciju, volonterske aktivnosti, nastavni plan i program koji podrazumeva i rad kod kuće, učestvovanje u donošenju odluka, politici škole, i saradnji sa zajednicom.

Jedan od najznačajnijih teorijskih koncepata negovanja parnerstva i uključenosti roditelja u školske aktivnosti dece je svakako tipologija koju je dala Epstein (Epstein et al., 2002, 2016), koja obuhvata sledeće oblike uključivanja roditelja:

a) Roditeljstvo kao osnovna odgovornost porodice, odnosi se na pomoć porodici u razvijanju veština roditeljstva i adekvatnih uslova za pružanje podrške deci tokom školovanja. Škole koje rade na partnerstvu sa porodicom pružaju roditeljima osnovne informacije o deci, o njihovoj bezbednosti i zdravlju, o ishrani, nadzoru, disciplini i drugim veštinama roditeljstva. Škole takođe pružaju porodicama informacije o izgradnji pozitivne kućne atmosfere koja omogućava učenje i razvoj učenika na svakom nivou obrazovanja. Neke škole pomažu roditeljima u njihovim osnovnim obavezama, kroz programe podrške porodicama, organizuju radionice u školi i na drugim lokacijama, rade na uspostavljanju roditeljske mreže i drugih oblika porodičnog obrazovanja, obuke i razmene informacija.

b) Komunikacija kao osnovna odgovornost škole, odnosi se na uspostavljanje efektivne dvosmerne komunikacije između porodice i škole usmerene na školske programe i napredovanje dece. Većina škola šalje roditeljima informacije o školskom programu i napretku učenika. Njihova komunikacija uključuje memorandume, obaveštenja, telefonske pozive. Škole i nastavnici sve više koriste govornu poštu, $e$-mail-ove i web-stranice da bi komunicirali sa porodicama. Učenici isporučuju informacije svojim porodicama od strane nastavnika, i nastavnicima od strane roditelja. Međutim, uloga učenika kao kurira, posrednika i tumača komunikacije između kuće i škole, nije dobro shvaćena. U istraživanju učenika koji pohađaju srednje škole oko $24 \%$ njih je izjavilo da odmah isporuče obaveštenja iz škole svojim roditeljima (Connors, Epstein, 1994). Ovaj procenat se može povećati, ukoliko se roditeljima da uputstvo da pitaju decu da li su im poslata neka obaveštenja iz škole, kao i ukoliko roditelji i nastavnici objasne deci važnost njihove uloge za uspešnost partnerstva između škole i porodice. Porodice takođe mogu doprineti ovom procesu slanjem pisama nastavicima u kojima ističu da cene korisne informacije koje dobijaju o deci i školskim programima.

c) Volontiranje roditelja $u$ školi, odnosi se na organizovanje roditelja dobrovoljaca za podršku školi i učenicima. U okviru ove vrsta uključenosti škola prepoznaje kapacitete roditelja u pogledu raspoloživog vremena i resursa kojima porodice raspolažu i uključuje ih u poboljšanje kvaliteta školskih programa i uspeha učenika. Roditelji, članovi porodice i drugi u zajednici mogu volontirati u školama, u učionicama i na drugim mestima. Volontiranje takođe, podrazumeva i dolazak u školu i prisustvovanje priredbama učenika, sportskim i drugim događajima. Škola može povećati broj volontera koji pomažu učenicima, nastavnicima i drugima, 
raznovrsnim rasporedima i zadacima tako da se sve porodice osećaju dobrodošlima da učestvuju kao volonteri ili publika. Volonteri mogu doprineti svojim vremenom i talentima u školi, kući i na drugim mestima. Publika može biti pozvana tokom dana, uveče, vikendom, tokom leta i praznika, kad god su članovi porodice slobodni. Aktivnosti mogu biti organizovane tako da se iskoriste znanja i kompetencije roditelja u cilju pružanja informacija o njihovim zanimanjima, iskustvima koja poseduju, sa ciljem da se obogate časovi nastave i prošire interesovanja učenika za budući poziv. Nadgledanje i obuka mogu biti korisne aktivnosti u nižim razredima kada je volontiranje usmereno na pomoć učenicima da steknu osnovne veštine, a u višim kada veštine i interesovanja učenika postanu dublja i raznovrsnija, dok individualna pažnja može pomoći adolescentima da bolje i lakše prevaziđu probleme adolescencije.

Epsteinova (Epstein, 2016) smatra da je volonter svako ko, bilo kada i bilo gde, podržava ciljeve škole i učenje dece. Ovo je jedna od mnogih redefinicija porodične uključenosti koja je potrebna da bi se povećao broj roditelja koji učestvuju u dečijem obrazovanju. Ova redefinicija menja način na koji škole identifikuju i broje porodice koje učestvuju kao "volonteri". Epsteinova navodi da svi roditelji mogu pomoći telefonirajući drugim roditeljima, članovima zajednice ili drugim korisnim kontaktima; asistirajući u školama rano ujutru, kasno po podne, uveče, vikendom, u danima odmora ili u neko drugo pogodno vreme. Nastavnici mogu organizovati i aktivirati volontere na različite načine. Oni mogu napraviti "liste želja" o tome koja vrsta pomoći bi dobro došla njima i njihovim učenicima, ili "dane talenata" za porodice sa specifičnim veštinama i talentima, u vreme koje se poklapa sa potrebama i ciljevima škole.

d) Podučavanje kod kuće kao učestvovanje u školskim aktivnostima odnosi se na uključivanje porodice u rešavanje domaćih zadataka i druge aktivnosti vezane za kurikulum, i učešće $u$ aktivnostima i odlukama vezanim za nastavni plan i program. Nastavnici mogu uputiti roditelje kako da nadgledaju, pomažu i učestvuju u učenju dece kod kuće, aktivnostima koje su povezane sa nastavnim planom i programom. Aktivnosti četvrte vrste omogućavaju roditeljima da se bolje upoznaju sa predmetima, nastavnim metodama, akademskim i drugim veštinama koje su potrebne da se prođe razred, radom dece u školi: kako da podrže, nadgledaju, polemišu i pomažu deci pri domaćem zadatku, kako da pomognu učenicima da se spreme za test, kako da pomognu u izboru kurseva, akademskih programa, u izboru škola.

Porodice moraju uraditi više nego samo pitati decu: "Kako je bilo danas u školi?"'smatra Epstein (Epstein, 2016). Ovo pitanje retko inicira informacije o tome šta su učenici učili, koje veštine su savladali, ili njihove ideje o nekim važnim temama i problemima. Pitanja tipa: "Šta si danas naučio iz matematike?" ili "Pročitaj mi nešto što si danas napisao." ili "Šta si danas saznao iz nauke?", kao i druga slična pitanja vezana za nastavu, podstiču razgovor izmedju roditelja i deteta o zanimljivim temama i omogućavaju roditeljima da pohvale decu za uloženi napor, veštine koje su savladali ili neke nove ideje koje imaju. Porodice koje na ovaj način kominicaraju sa decom, upućene su u školske aktivnosti. Komunikacija takođe može početi i primerima iz stvarnog života i kako se u praksi koriste veštine čitanja i matematika. 
Na mnogo načina, porodice mogu pomoći deci da uvide da su veštine stečene u školama upotrebljive u svakodnevnom životu (Moll et al., 1992).

e) Donošenje odluka, kao participacija i rukovođenje, odnosi se na uključivanje porodice u donošenje odluka i podsticanje učešća u rukovođenju. Škola podstiče učestvovanje roditelja u donošenju školskih odluka ohrabrujući organizaciju roditeljskih udruženja i uključivanje roditelja i predstavnika zajednice u školska veća i odbore. Neki roditelji preuzimaju lidersku ulogu i aktivno učestvuju u školskim timovima, većima, roditeljskim organizacijama i odborima. Drugi roditelji ne žele da budu aktivni ili imaju malo vremena za to, ali žele da budu informisani i konsultovani o školskim odlukama, koje se tiču njihove dece (Connors, Epstein, 1994).

f) Saradnja sa lokalnom zajednicom odnosi se na usklađivanjemeđusobnih potreba porodice, škole i lokalne zajednice. Škola se povezuje sa lokalnom samoupravom, sa institucijama u zajednici, sa verskim organizacijama, kulturnim udruženjima, starijim građanima i drugim grupama koje dele interesovanje i odgovornost za obrazovanje i uspeh dece (Epstein, 2016., Sanders, 2001). Škole i grupe roditelja mogu raditi na tome da informišu učenike i porodice o programima zajednice i uslugama podrške, da povećaju mogućnosti porodica i dece da pristupe ovim programima i uslugama. Ovo podrazumeva vanškolske programe, letnje aktivnosti, zdravstvene usluge, kulturne događaje, i druge povlastice. Saradnja sa zajednicom treba da bude dizajnirana da pomogne učenicima i njihovim porodicama da dobiju željene usluge i školama da poboljšaju nastavne i vannastavne planove i programe.

Partnerstvo porodice, škole i zajednice kroz šest vrsta angažovanja podrazumeva mnogo načina na koje škole uključuju roditelje i roditelji preuzimaju odgovornost za obrazovanje dece. Kada se roditelji uključe, oni uče o školskim programima i ciljevima obrazovanja u školi, efektivnije podržavaju učenje dece kod kuće, i adekvatnije utiču na kasnije obrazovanje svoje dece. Pravo partnerstvo između roditelja, nastavnika i članova zajednice nastaje kada sve strane svoje aktivnosti fokusiraju na učenje i uspeh dece. Epstein navodi da su nastavnici i uprava škole odgovorni za projektovanje sveobuhvatne strategije za partnerstvo, za postizanje uključenosti roditelja (Epstein, 2016). Zaključak mnogih teoretičara je da se suština uspešnog partnerskog odnosa između porodice i škole nalazi u naporima za sveobuhvatnu reformu obrazovanja u školi. To podrazumeva programe efikasnog uključivanja roditelja u školske aktivnosti kroz izgradnju sistema partnerstva koji dovodi do optimalnog razvoja svakog deteta. Brojna istraživanja pokazuju da roditelji koji su uključeni u školske aktivnosti dece, pohađanjem roditeljskih sastanaka, praćenjem napretka svoje dece, pomaganjem deci u domaćim zadacima, imaju decu sa odličnim akademskim postignućima (Epstein et al., 2002; Steinberg et al., 1992; Steinberg, Lamborn et al., 1992; Stevenson \& Baker, 1987; Matejevic, Jovanovic, 2014).

\section{Metodološki pristup problemu}

Istraživanje je bilo organizovano sa ciljem da se utvrde oblici uključenosti roditelja u školske aktivnosti njihove dece. Pošli smo od pretpostavke da postoje 
različiti oblici uključenosti roditelja u školske aktivnosti, kao i da postoje statistički značajne razlike u stepenu uključenosti roditelja u školske aktivnosti u odnosu na pol, i nivo obrazovanja roditelja, kao i u odnosu na uspeh i uzrast učenika U istraživanju je korišćena deskriptivna naučno-istraživačka metoda, tehnika skaliranja, i skala procene koja je konstruisana za potrebe ovog istraživanja, u skladu sa tipologijom Epsteinove, koja je sadržala 36 stavki. Subjekt istraživanja bili su roditelji učenika osnovnih i srednjih škola, 100 roditelja dece osnovnoškolskog uzrasta, 100 roditelja dece srednjoškolskog uzrasta. Upitnike su popunjavali posebno očevi, posebno majke. Kronbahov $\alpha$ koeficijent pouzdanosti skale na ispitanom uzorku iznosi 0.750 , što ukazuje na adekvatnost instrumenta.

\section{Rezultati istraživanja}

$\mathrm{Na}$ osnovu statističke obrade podataka i faktorske analize utvrđeni su osnovni oblici uključenosti majki u školske aktivnosti, rezultati su prikazani u tabeli br 1. Dobijeni rezultati pokazuju da je uključenost majki u školske aktivnosti najizraženija u komunikaciji sa školom i učenjem kod kuće, što se odnosi na redovno informisanje o dešavanjima u školi, i podršku detetu kada mu je pomoć potrebna. U prilog tome idu i rezultati brojnih istraživanja koji pokazuju da su podsticanje, hrabrenje, podrška i zainteresovanost za probleme u učenju od posebnog značaja za školsko postignuće učenika (Steinberg et al., 1992). Na drugom mestu se nalazi uključivanje u sve školske aktivnosti, ovaj faktor podrazumeva da su majke redovno informisane i uključene u dešavanja u školi, da se aktivno uključuju u sve volonterske aktivnosti u školi. Ova dva faktora pokrivaju većinu ajtema u merenju majčinske uključenosti u školski život dece, poklapaju se delimično sa tri tipa roditeljske uključenosti koju navodi Epstein (Epstein), i to su: komunikacija, pomoć u učenju kod kuće i volontiranje. Ostali parametri koji pokazuju uključenost majke u školske aktivnosti dece su znatno niži, pre svega uključivanje u vannastavne aktivnosti, nedostatak vremena, i očekivanje inicijative od strane škole.

Tabela 1. Oblici uključenosti majke u školske aktivnosti dece

\begin{tabular}{cccccc}
\hline & \multicolumn{3}{c}{ Empirijski raspon } \\
\hline & $\begin{array}{c}\text { Saradnja i } \\
\text { komunikacija sa } \\
\text { školom }\end{array}$ & $\begin{array}{c}\text { Uključivanje u } \\
\text { van nastavne } \\
\text { aktivnosti }\end{array}$ & $\begin{array}{c}\text { Očekivanje } \\
\text { školske } \\
\text { inicijative }\end{array}$ & $\begin{array}{c}\text { Nedostatak } \\
\text { vremena za } \\
\text { uključivanje } \\
\text { u školske } \\
\text { aktivnosti }\end{array}$ & $\begin{array}{c}\text { Uključivanje } \\
\text { u sve školske } \\
\text { aktivnosti }\end{array}$ \\
AS & 43,27 & 17,18 & 12,48 & 12,92 & 24,91 \\
SD & 9,62 & 6,08 & 4,39 & 4,30 & 5,020 \\
Min & 20,00 & 7,00 & 5,00 & 4,00 & 11,00 \\
Max & 62,00 & 35,00 & 23,00 & 20,00 & 68,00 \\
$n$ & 200 & 200 & 200 & 200 & 200 \\
\hline
\end{tabular}


Ovi podaci pokazuju da su majke samoinicijativne kada je u pitanju uključivanje u školske aktivnosti dece, da ne očekuju inicijativu od strane škole i da ukoliko zaista žele da se uključe u rad škole to zapravo i rade, informišući se same ili preko deteta. Većina majki redovno pohađa roditeljske sastanke i one su te koje pokušavaju da uspostave saradnju sa školom. Dakle, inicijativa za uključenost majki u školski život dece potiče od njih samih.

Kada analiziramo rezulate uključenosti očeva u školske aktivnosti, možemo videti da postoje sličnosti u odnosu na uključenost majki, ali i razlike. I kod njih je najizraženiji faktor koji se odnosi na saradnju i komunikaciju sa školom, samo je stepen njihove uključenosti niži u odnosu na uključenost majki. Rezultati su prikazani u tabeli br. 2.

Tabela 2. Oblici uključenosti oca u školske aktivnosti dece

\begin{tabular}{cccccccc}
\hline \multicolumn{7}{c}{ Empirijski raspon } \\
\hline & $\begin{array}{c}\text { Saradnja i } \\
\text { komunikacija } \\
\text { sa školom }\end{array}$ & $\begin{array}{c}\text { Očekivanje } \\
\text { školske } \\
\text { inicijative }\end{array}$ & $\begin{array}{c}\text { Pomaganje } \\
\text { detetu u } \\
\text { skolskim } \\
\text { obavezama }\end{array}$ & $\begin{array}{c}\text { Saradnja sa } \\
\text { nastavnicima }\end{array}$ & $\begin{array}{c}\text { Uključivanje } \\
\text { u vannastavne } \\
\text { aktivnosti }\end{array}$ & $\begin{array}{c}\text { Uključivanje } \\
\text { u sve školske } \\
\text { aktivnosti }\end{array}$ & $\begin{array}{c}\text { Nedostatak } \\
\text { vrema za } \\
\text { ukljuchanje } \\
\text { u školske } \\
\text { aktivnosti }\end{array}$ \\
AS & 27,47 & 18,25 & 13,88 & 15,23 & 11,09 & 6,28 & 7,23 \\
SD & 6,09 & 4,14 & 3,19 & 3,93 & 3,31 & 2,11 & 2,12 \\
Min & 13,00 & 8,00 & 4,00 & 5,00 & 4,00 & 2,00 & 2,00 \\
Max & 41,00 & 28,00 & 20,00 & 24,00 & 18,00 & 10,00 & 10,00 \\
$n$ & 200 & 200 & 200 & 200 & 200 & 200 & 200 \\
\hline
\end{tabular}

Na drugom mestu se nalazi faktor koji se odnosi na inicijativu škole, što kazuje da očevi imaju očekivanja da škola bude inicijator saradnje, za razliku od majki, koje su spremne da preuzmu inicijativu i uzmu učešće u školskim aktivnostima dece. Treći faktor koji se odnosi na saradnju sa nastavnicima pokazuje da određeni broj očeva želi da svoje slobodno vreme iskoristi uključivanjem u školske aktivnosti, ali da ne znaju kako bi se uključili, kao i da inicijativu očekuju od škole. Ostala četiri faktora odnose se na pomaganje detetu u školskim obavezama, uključivanje u vannastavne aktivnosti i nedostatak vremena za uključivanje u školske aktivnosti.

U odnosu na obrazovanje roditelja, kod majki nisu utvrđene statistički značajne razlike između uključenosti u aktivnosti škole i nivoa obrazovanja. Kod očeva su pak utvrđene statistički značajne razlike: na nivou 0,05 u odnosu na faktor saradnje i komunikacije, i 0,01 u odnosu na faktor pomoć detetu u školskim obavezama, što ukazuje da je viši nivo obrazovanja očeva povezan sa značajnijim uključivanjem u školske aktivnosti dece.

U odnosu na uzrast učenika, izračunavanjem Pirsonovog koeficijenta korelacije uključenosti roditelja (majka, otac) u školske aktivnosti dece sa uzrastom dece dobijen je sledeći rezultat - postoji statistički značajna povezanost. Kod majki je prisutna pozitivna korelacija kod faktora saradnja i komunikacija sa školom, značajna na nivou 0.01, što je dete mlađe, to se majke više uključuju u školski život deteta. Kod očeva takođe postoji samo u okviru faktora pomaganje detetu u školskim obavezama: što je dete mlađe, to se očevi više uključuju u pružanju podrške deci u školskim obavezama, korelacija je značajna na nivou 0.05. Rezultati su prikazani u tabelama 3 i 4. 
Tabela 3. Razlike u uključenosti majke u školske aktivnosti s obzirom na uzrast

\begin{tabular}{ccccccc}
\hline & & n & AS & SD & F test & Nivo značajnosti \\
\hline $\begin{array}{c}\text { Saradnja i } \\
\text { komunikacija sa } \\
\text { školom }\end{array}$ & $\begin{array}{c}\text { Adolescenti } \\
\text { Deca o osn. }\end{array}$ & 100 & 40,2400 & 10,50360 & & \\
školi & 100 & $\mathbf{4 6 , 3 0 0 0}$ & 7,57254 & 21,902 & $\mathbf{0 0 0}$ \\
& ukupno & 200 & 43,2700 & 9,62498 & & \\
\hline
\end{tabular}

Tabela 4. Razlike u uključenosti oca u školske aktivnosti s obzirom na uzrast

\begin{tabular}{ccccccc}
\hline & & n & AS & SD & F test & $\begin{array}{c}\text { Nivo } \\
\text { značajnosti }\end{array}$ \\
\hline $\begin{array}{c}\text { Pomaganje } \\
\text { detetu u } \\
\text { školskim } \\
\text { obavezama }\end{array}$ & Adolescenti & 100 & 13,3400 & 3,47057 & & \\
\hline
\end{tabular}

Kada je u pitanju uspeh učenika, rezultati istraživanja su pokazali da postoji statistički značajna razlika u saradnji i komunikaciji sa školom u odnosu na uspeh učenika u školi. Dobijeni rezultati su pokazali da je faktor saradnje i komunikacije sa školom povezan sa postignućima učenika, da majke i očevi koji su uključeniji u aktivnosti škole kroz komunikaciju sa školom imaju decu koja imaju bolja postignića. Dobijeni nalazi su u skaldu sa nekim drugim istraživanjima (Steinberg, Lamborn et al., 1992), što potvrđuje značaj uključenosti roditelja u školske aktivnosti za postignuća učenika. Rezultati su prikazeni u tabelama 5 i 6.

Tabela 5. Uključenosti majke u školske aktivnosti i uspeh učenika

\begin{tabular}{ccccccc}
\hline & n & AS & SD & F test & $\begin{array}{c}\text { Nivo } \\
\text { značajnosti }\end{array}$ \\
\hline $\begin{array}{c}\text { Saradnja i } \\
\text { komunikacija sa }\end{array}$ & odličan & 88 & $\mathbf{4 4 , 7 7 2 7}$ & 7,65300 & & \\
školom & dobar & 45 & 38,1333 & 12,53287 & & \\
& dovoljan & 1 & 61,0000 & $\cdot$ & 7,070 & $\mathbf{0 0 0}$ \\
& ukupno & 200 & 43,2700 & 9,62498 & & \\
\hline
\end{tabular}

Tabela 6. Uključenosti oca u školske aktivnosti i uspeh učenika

\begin{tabular}{ccccccc}
\hline & & n & AS & SD & F test & $\begin{array}{c}\text { Nivo } \\
\text { značajnosti }\end{array}$ \\
\hline Saradnja i & odličan & 88 & $\mathbf{2 8 , 4 6 5 9}$ & 5,83676 & & \\
komunikacija sa & vrlo dobar & 66 & 25,8030 & 6,65460 & & \\
školom & dobar & 45 & 27,8222 & 5,27554 & 3,078 & $\mathbf{, 0 2 9}$ \\
& dovoljan & 1 & 35,0000 &. & \\
& ukupno & 200 & 27,4750 & 6,09798 & & \\
\hline
\end{tabular}




\section{Zaključak}

Na osnovu dobijenih rezultata možemo zaključiti da se uključenost roditelja u školske aktivnosti, prema tipologiji Epsteinove (Epstein, 2016), nalazi na nivou komunikacije, pomoći u učenju kod kuće i volontiranja, što ukazuje na to da nisu zastupljeni svi oblici uključenosti roditelja u školske aktivnosti. Roditelji dobijaju informacije od škole o uspehu, napredovanju dece, ali nisu pozivani da se dublje uključe u školske aktivnosti dece, pri čemu škola jeste otvorena za saradnju ukoliko sami roditelji pokažu inicijativu za uključivanje u školske aktivnosti dece. Stepen participacije roditelja je na tom nivou da će ona postojati ukoliko sami roditelji pokažu inicijativu. Roditelji su naveli da očekuju veću inicijativu od strane škole za njihovo uključivanje u školske aktivnosti, pri čemu su očevi ti koji očekuju veću inicijativu od strane škole, za razliku od majki, koje u većoj meri pokazuju samoinicijativu i želju da se uključe u školske aktivnosti dece. U odnosu na nivo obrazovanja roditelja, utvrđeno je da postoji statistički značajna razlika između uključenosti očeva i nivoa obrazovanja, viši nivo obrazovanja očeva, povezan je sa većom participacijom u školskim aktivnostima, kod majki ove razlike nisu utvrđene. Kada je u pitanju uzrast učenika, kod mlađih učenika, uključenost roditelja u školske aktivnosti je veća, što je u saglasnosti i sa nekim ranijim istraživanjima. Takođe je utvrđena povezanost uključenosti roditelja sa uspehom učenika, roditelji koji su pokazali veći stepen uključenosti, imaju decu sa boljim školskim postignućima, što je u skladu sa rezultatima nekih ranijih istraživanja. Implikacije dobijenih nalaza pokazuju da je potrebno da škola preuzme inicijativu za uključivanje roditelja u školske aktivnosti, kroz negovanje različitih oblika partnerstva porodice i škole. Potrebno je dodatno angažovanje pedagoško-psihološke službe u školi u kontekstu razvoja nastavničkih kompetencija za uspostavljanje partnerstva sa porodicom i uključivanja roditelja u školske aktivnosti, s obzirom da porodica i škola, imaju zajedničke interese i odgovornosti prema deci u stvaranju boljih programa i prilika za razvoj i postignuća učenika

\section{Literatura}

Connors, L. J. \& Epstein, J. L. (1994). Taking stock: Views of teachers, parents, and students on school, family, and community. Partnerships in High Schools. (Rep. No. 25). Baltimore, MD: Johns Hopkins University, Center on Families, Communities, Schools, and Children's Learning.

Driessen, G. Smit, F. \& Sleegers F. (2005). Parental Invovement and Educational Achievement. Britisch Educational Reserch Journal. Vol. 31, 4. p. 509-532.

Džinović, V., Pavlović, J. \& Milošević, N. (2007). Saradnja porodice i škole kao odnos međuzavisnosti: kako roditelji konstruišu probleme, Zbornik, Saradnja porodice $i$ škole, Institut za pedagoška istraživanja, Beograd.

Epstein, J. L. (2016). School, family, and community partnerships: Preparing educators and improving schools (2nd ed.). Philadelphia, PA: Westview Press. 
Epstein, J. et al. (2002). School, family, and community partnerships: Your handbook for action (2nd ed.). Thousand Oaks, CA: Corwin Press.

Matejevic, M., Jovanovic, D. \& Jovanovic, M. (2014). Parenting Style, Parents' Involvement in School Activities and Adolescents' Academic Achievement. Procedia - Social and Behavioral Sciences, Vol. 128, p. 288-293.

Moll, L. C., Amanti, C., Neff, D. \& Gonzalez, N. S. (1992): Theory into Practice, Qualitative Issues in Educational Research, Vol. 31, No. 2, 132-141.

Polovina, N. (2007). Sistemska analiza saradnje škole i porodice, Zbornik, Saradnja porodice $i$ škole, Institut za pedagoška istraživanja, Beograd.

Sanders, M. G. (2001). The role of Community in comprehensive School, Family, and Community Partnership Programs. The Elementary School Journal, 102 (1), 19-33.

Steinberg, L., Dornbusch, S. M. \& Brown, B. B. (1992). Ethnic differences in adolescent achievement: An ecological perspective. American Psychologist, 47(6), 723-729.

Steinberg, L., Lamborn, S., Dornbusch, S. \& Darling, N. (1992). Impact of Parenting Practices on Adolescent Achievement: Authoritative Parenting, School Involvement, and Encouragement to Succeed, Child Development, 63, 1266-1281.

Swap, S. M. (1993). Developing Home-school partnerships: From concepts to practice. New York: Teachers College Press.

Stevenson, D. L. \& D. P. Baker (1987): The family-school relation and the child's school performance, Child Development, Vol. 58, No. 5, 1348-1357.

\title{
PARENT INVOLVEMENT IN SCHOOL ACTIVITIES
}

\author{
Marina Matejević, Marija Jovanović \\ University of Niš, Faculty of Philosophy in Niš, Department of Pedagogy
}

Abstract: The paper discusses the problem of parent involvement in school activities.
As a theoretical starting point, the Epstein model (Epstein, 2016) is referred to, the
problems of achieving family and school partnerships, in the context of involving
parents in school activities. The research was organized with the aim of determining
the forms of parent involvement in school activities, and differences in gender and
level of parenting, and the success and age of students. The results of the research
have shown that parent involvement in the school activities according to Epstein's
typology is at the level of communication, home learning and volunteering, whereby
the school is open to cooperation, if the parents themselves show the initiative for
inclusion in school activities. The results of the research have shown that mothers are
more involved in school activities, have an initiative to establish partnerships with
school, while fathers expect the school's initiative. In relation to the level of education
of parents, it was established that there is a statistically significant difference between
the involvement of fathers and the level of education, in the case of mothers this
difference has not been determined. In younger students, parent involvement in school
activities is higher, which is in line with some previous research. It has also been found 
that the involvement of parents in school activities with the success of pupils, parents who have shown greater inclusion, have children with better school achievements. The implications of the findings reveal that the school needs to take the initiative to organize family relationships in the context of using different possibilities of involving parents and fostering partnerships, since family and school have shared interests and responsibilities towards children in creating better programs and opportunities for development and achievements of students.

Key words: Parental involvement, school activities, family and school partnerships.

\section{Citiranje članka:}

Matejević, M. i Jovanović, M. (2017). Uključenost roditelja u školske aktivnosti. Godišnjak za pedagogiju, 2(1), 9-20. 